\section{NEW DERIVATIVES: 2,4,5-TRISUBSTITUTED-1,3-THIAZOLE ANTIMICROBIAL ACTIVITY AND IN SILICO STUDY}

Iswatun Hasanah Abdullah Ripaina, Deny Susantia, Noraslinda Muhamad Bunnorib, Nurziana Ngaha*

aDepartment of Chemistry, Kulliyyah of Science, International Islamic University Malaysia, Kuantan Campus, Jalan Sultan Ahmad Shah, 25200 Kuantan, Pahang, Malaysia

bDepartment of Biotechnology, Kulliyyah of Science, International Islamic University Malaysia, Kuantan Campus, Jalan Sultan Ahmad Shah, 25200 Kuantan, Pahang, Malaysia
Article history

Received

8 March 2019

Received in revised form

10 December 2019

Accepted

16 January 2020

Published online

27 February 2020

*Corresponding author nurziana@iium.edu.my

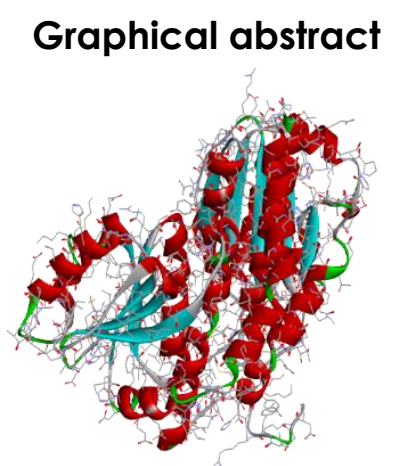

Glucosamine-6-Phosphate synthase downloaded from www.rcsb.org

\begin{abstract}
A series of thiazole derivatives 1-4 were synthesized employing simple one-pot reaction pathway and characterized via Fourier Transform Infrared (FTIR), Proton Nuclear Magnetic Resonance ('H NMR), Ultraviolet-Visible (UV-Vis) and Gas Chromatography-Mass Spectrometry (GC-MS). The newly synthesized compounds were evaluated for their in vitro antimicrobial properties against several bacterial strains including Gram-positive and Gram-negative as well as fungus using broth microdilution method. The results revealed that all of the compounds exhibited good activity with a range of MIC values between $1.25-5.0 \mathrm{mg} / \mathrm{mL}$. From the MIC and MBC results, compound 1 exhibited good activities with same MIC value of $1.25 \mathrm{mg} / \mathrm{mL}$ and $M B C$ value of $5 \mathrm{mg} / \mathrm{mL}$ against $B$. cereus and $S$. flexneri. In order to support antimicrobial results, the molecular docking studies were carried out for inhibition of the GlcN-6-P synthase as the target. Out of four compounds underwent for molecular docking studies, 5-acetyl-4-methyl-2-(4-aminobiphenyl)-1,3thiazole (1) shows the lowest minimum binding energy at $-7.32 \mathrm{kcal} / \mathrm{mol}$ as compared to 2,3 and 4 with $-7.31,-7.20$ and $-6.76 \mathrm{kcal} / \mathrm{mol}$, respectively which are in agreement with antimicrobial assay results. In conclusion, 2, 4, 5-trisubstituted- 1,3- thiazole derivatives could be considered as promising antimicrobial in drug discovery candidates.
\end{abstract}

Keywords: Thiazole derivatives, antimicrobial, GlcN-6-P synthase, molecular docking

\begin{abstract}
Abstrak
Satu siri terbitan tiazol 1-4 telah disintesis menggunakan tindak balas mudah 'one-pot' dan dicirikan dengan kaedah spektroskopi Transformasi Fourier-Inframerah (FTIR), Proton Resonans Magnetik Nukleus ('H NMR) dan Sinar tampak ultraviolet (UV-Vis) serta Kromatografi Jisim Gas-Spektrometer (GC-MS). Sebatian baru yang disintesis ini telah diuji sebagai sebatian yang bercirikan antimikrob secara 'in-vitro'. Ciri antimikrob ini telah diuji terhadap beberapa strain bakteria iaitu Gram-positif dan Gram-negatif serta fungus menggunakan kaedah kaldu mikrocairan. Keputusan mendapati kesemua sebatian yang diuji (1-4) mempunyai aktiviti di dalam julat nilai MIC diantara 1.25-5.0 mg/mL. Daripada nilai bacaan MIC dan MBC, sebatian 1 menunjukkan aktiviti yang bagus dengan nilai MIC pada $1.25 \mathrm{mg} / \mathrm{mL}$ dan $M B C$ pada $5 \mathrm{mg} / \mathrm{mL}$ terhadap B. cereus dan S. flexneri. Seterusnya, kajian penyatuan molekul dilakukan ke atas semua sebatian (1-4) untuk merencat GlcN6-P sintase yang digunakan sebagai sebatian sasaran. Diantara empat molekul yang diuji, 5-asetil-4-metil-2-(4-aminobifenil)-1,3-tiazol (1) menunjukkan tenaga pengikatan minimum
\end{abstract}


yang paling rendah iaitu $-7.32 \mathrm{kcal} / \mathrm{mol}$ berbanding dengan sebatian $\mathbf{2}, \mathbf{3}$ dan $\mathbf{4}$ dengan nilai masing-masing iaitu $-7.31,-7.20$ dan $-6.76 \mathrm{kcal} / \mathrm{mol}$ selari dengan keputusan ujian antimikrobial. Kesimpulannya, ujian selanjutnya boleh dilakukan ke atas sebatian terbitan 1,3-tiazo berpenggantian-2, 4, 5 di dalam mencari sebatian baru dalam bidang penemuan ubatan baru.

Kata kunci: Terbitan tiazol, antimikrobial, GlcN-6-P sintase, penyatuan molekul

(C) 2020 Penerbit UTM Press. All rights reserved

\subsection{INTRODUCTION}

The past decade has seen the third world countries faced serious health problems caused by microorganisms such as pneumonia, bacteremia, typhoid, malaria, urinary tract infections, cough and other infections [1, 2]. All the diseases stated are caused by microorganisms that give severe symptoms for example nausea, vomiting, diarrhea, food poisoning and fever [3, 4]. Hence, the investigations and development of efficient and powerful antibiotics become an urgent demand for inhibition of those microorganisms. Antibiotic resistance has become challenges to the researchers to create new types of antimicrobial agents that can expand the old antibiotic's bio-utility [5]. Thiazole and their derivatives have attracted unending interest over the years for their numerous biological activities [6]. It is also reported that thiazole ring moiety appears almost in the commercialized antibiotics and antiparasitic such as acinitrazole, penicillin, nitazoxanide, aminitrozle and various synthetic drugs in markets [7, 8, 9]. Recent surveys showed that thiazole compounds play important role as antibacterial, anti-inflammatory, anticonvulsant and anticancer agents [10, 11]. Structural activity relationship (SAR) study based on thiazole revealed that substituents on a particular position at position 2 and 4 of the 1,3-thiazole ring affect the biological behavior $[12,13]$. Other than that, molecular docking study is a computer-assisted drug design (CADD) that is used to predict eligible orientation of ligand towards specific receptor. In this study, type of interaction such as hydrogen bonding between ligand and receptor can be determined [8, 14].

The target receptor namely Glucosamine-6phosphate synthase or known as GlcN-6-P synthase plays an important role as protection and building block of all types of cell in bacterial strains $[15,16]$. As commonly known, inhibition of this enzyme will reduce the life-time of bacteria. These attributes suggest that GlcN-6-P synthase could be the main target for creating novel antimicrobial drugs with high selectivity and low-toxicity antibacterial activity. Taking into consideration of these properties, we designed a series of 1,3 thiazole derivatives, in which a bulky amine substituent was incorporated into the $2^{\text {nd }}$ position, methyl group onto the $4^{\text {th }}$-position and acetyl group moiety was placed at the $5^{\text {th }}$-position of heterocyclic ring. Then, their antimicrobial properties towards selected microorganisms were tested. Molecular docking studies of the synthesized compounds were also performed for better understanding on interaction between the ligands and GlcN-6-P synthase (receptor).

\subsection{EXPERIMENTAL}

\subsection{Materials and Methods}

All chemicals (reagent and solvent) were purchased from Merck, Sigma-Aldrich and $\mathrm{HmbG}^{\circledR}$ Chemicals Malaysia. The purity of these chemicals was $90-99 \%$ and used without further purification and distillation.

\subsection{General Experimental Procedures}

Melting points of the synthesized compounds were determined (uncorrected) using Stuart Scientific Melting Point Apparatus SMP3. 'H spectra (500 MHz) were recorded on NMR machine Bruker Ultra Shield Plus spectrometer using deuterated dimethyl sulfoxide-do (DMSO-do) as solvent and at room temperature and tetramethylsilane (TMS) as an internal standard. Infrared (IR) spectra were recorded on Perkin Elmer FTIR GX spectrometer using $\mathrm{KBr}$ pellets. UV-Vis spectra were recorded via ShidmadzU UV1601PC spectrophotometer using methanol as solvent. Mass spectra were obtained from Perkin Elmer GC-MS (Clarus 500 Chromatography/ Mass Spectrometry) in electron impact (El) ionization mode (70eV) by dissolving the synthesized compounds in methanol.

\subsubsection{General Procedures for the Synthesis of 2,4,5 Trisubstituted-1,3-Thiazole Derivatives}

3-Chloroacetyl acetone $(5.0 \mathrm{mmol}, 0.67 \mathrm{~g})$ was reacted with ammonium thiocyanate $(5.0 \mathrm{mmol}, 0.38$ g) in acetone and the mixture was stirred for 15 minutes at room temperature. Stirring was stopped after the formation of salt and the selected primary amine derivatives $(5.0 \mathrm{mmol}, 0.16 \mathrm{~g})$ were added and refluxed at ca. 3 hours. The reaction was carried out to give yellow solution with white precipitate as by products. After completion of the reaction, the 
reaction mixture was cooled to room temperature and filtered. The precipitate formed was filtered, dried and recrystallized from methanol to give thiazole derivatives (1-4).

5-Acetyl-4-methyl-2-(4-aminobiphenyl)-1,3-thiazole (1) Yellow powder, yield: $74 \%$; m.p: $201-202{ }^{\circ} \mathrm{C}$; ${ }^{1} \mathrm{H}$ NMR $\left(500 \mathrm{MHz}, \mathrm{DMSO}-\mathrm{d}_{6}\right): \delta_{\mathrm{H}} 2.44\left(\mathrm{~s}, 3 \mathrm{H}, \mathrm{CH}_{3}\right), 2.57$ (s, 3H, $\left.\mathrm{CH}_{3}\right), 7.33(\mathrm{t}, J 7 \mathrm{~Hz}, 1 \mathrm{H}, \mathrm{Ar}-\mathrm{CH}), 7.45(\mathrm{t}, J 8 \mathrm{~Hz}, 2 \mathrm{H}, \mathrm{Ar}-$ $\mathrm{CH}), 7.66(\mathrm{~d}, J 7.5 \mathrm{~Hz}, 2 \mathrm{H}, \mathrm{Ar}-\mathrm{CH}), 7.69$ (pseudo-d, J 9 $\mathrm{Hz}, 2 \mathrm{H}, \mathrm{Ar}-\mathrm{CH}$ ), 7.70 (pseudo-d, J $9 \mathrm{~Hz}, 2 \mathrm{H}, \mathrm{Ar}-\mathrm{CH}$ ), 10.89 (s, $1 \mathrm{H}, \mathrm{NH}$ of thiazole). IR (KBr pellet): $v(\mathrm{~N}-\mathrm{H}) 3261 \mathrm{~cm}^{-1}$, $\vee$ (aromatic C-H) $3057 \mathrm{~cm}^{-1}, v(\mathrm{C}=\mathrm{O}) 1611 \mathrm{~cm}^{-1}, v(\mathrm{C}=\mathrm{N})$ $1547 \mathrm{~cm}^{-1}, \vee(\mathrm{C}-\mathrm{S}) 756 \mathrm{~cm}^{-1}$. UV-Vis $(\mathrm{MeOH}): \lambda_{\text {abs }}\left(\pi-\Pi^{*}\right)$ $208 \mathrm{~nm}, 7070 \mathrm{M}^{-1} \mathrm{~cm}^{-1}$; $\lambda$ abs (Mixed $\pi-\Pi^{*}$ and $\mathrm{n}-\Pi^{*}$ ) 209 $\mathrm{nm}, 6730 \mathrm{M}^{-1} \mathrm{~cm}^{-1} ; \lambda_{\text {abs }}\left(\mathrm{n}-\pi^{*}\right) 277 \mathrm{~nm}, 3720 \mathrm{M}^{-1} \mathrm{~cm}^{-1} ; \lambda_{\text {abs }}$ (п-ா") $355 \mathrm{~nm}, 7680 \mathrm{M}^{-1} \mathrm{~cm}^{-1}$. MW: 308.10; MS: m/z $308.12\left(\mathrm{M}^{+}\right)$.

5-Acetyl-4-methyl-2-(4-isopropylaniline)-1,3-thiazole (2) Yellow powder, yield: 70\%; m.p: $130-132{ }^{\circ} \mathrm{C}$; ${ }^{1} \mathrm{H}$ NMR $\left(500 \mathrm{MHz}, \mathrm{DMSO}-\mathrm{d}_{6}\right): \delta_{\mathrm{H}} 1.19\left(\mathrm{~s}, 6 \mathrm{H}, 2 \times \mathrm{CH}_{3}\right), 2.41(\mathrm{~s}, 3 \mathrm{H}$, $\left.\mathrm{CH}_{3}\right), 2.53\left(\mathrm{~s}, 3 \mathrm{H}, \mathrm{CH}_{3}\right), 2.84(\mathrm{~m}, J 7 \mathrm{~Hz}, 1 \mathrm{H}, \mathrm{CH}), 7.23$ (pseudo-d, J $8.5 \mathrm{~Hz}, 2 \mathrm{H}, \mathrm{Ar}-\mathrm{CH}$ ), 7.50 (pseudo-d, J 8.5 $\mathrm{Hz}, 2 \mathrm{H}, \mathrm{Ar}-\mathrm{CH}), 10.71(\mathrm{~s}, 1 \mathrm{H}, \mathrm{NH}$ of thiazole). IR ( $\mathrm{KBr}$ pellet): $v(\mathrm{~N}-\mathrm{H}) 3281 \mathrm{~cm}^{-1}, v$ (aromatic $\left.\mathrm{C}-\mathrm{H}\right) 3081 \mathrm{~cm}^{-1}$, $v(C=O) 1614 \mathrm{~cm}^{-1}, v(C=N) 1523 \mathrm{~cm}^{-1}, v(C-S) 833 \mathrm{~cm}^{-1}$. UV-Vis (MeOH): $\lambda_{\text {abs }}\left(M i x e d ~ \pi-\pi^{*}\right.$ and $\left.n-\pi^{*}\right) 208 \mathrm{~nm}, 6270$ $\mathrm{M}^{-1} \mathrm{~cm}^{-1}$; $\lambda_{\text {abs }}$ (Mixed $\pi-\Pi^{*}$ and $\left.\mathrm{n}-\Pi^{*}\right) 235 \mathrm{~nm}, 5030 \mathrm{M}$ ${ }^{1} \mathrm{Cm}^{-1}$; $\lambda_{\text {abs }}\left(\Pi-\Pi^{*}\right) 351 \mathrm{~nm}, 9270 \mathrm{M}^{-1} \mathrm{~cm}^{-1}$. MW: 274.11 ; MS: $\mathrm{m} / \mathrm{z} 274.10\left(\mathrm{M}^{+}\right)$.

5-Acetyl-4-methyl-2-(4-ethylaniline)-1,3-thiazole (3) Yellow powder, yield: $76 \%$; m.p: $124-126{ }^{\circ} \mathrm{C} ;{ }^{1} \mathrm{H}$ NMR (500 MHz, DMSO-d $d_{6}$ ): $\delta_{H} 1.17\left(t, J 7.5 \mathrm{~Hz}, 3 \mathrm{H}, \mathrm{CH}_{3}\right), 2.41$ $\left(\mathrm{s}, 3 \mathrm{H}, \mathrm{CH}_{3}\right), 2.51\left(\mathrm{~s}, 3 \mathrm{H}, \mathrm{CH}_{3}\right), 2.57\left(\mathrm{~s}, 3 \mathrm{H}, \mathrm{CH}_{2}\right), 7.21$ (pseudo-d, J $8 \mathrm{~Hz}, 2 \mathrm{H}, \mathrm{Ar}-\mathrm{CH}$ ), 7.50 (pseudo-d, J $8.5 \mathrm{~Hz}$, $2 \mathrm{H}, \mathrm{Ar}-\mathrm{CH}), 10.71(\mathrm{~s}, 1 \mathrm{H}, \mathrm{NH}$ of thiazole). IR (KBr pellet): $\vee(\mathrm{N}-\mathrm{H}) 3270 \mathrm{~cm}^{-1}, v$ (aromatic C-H) $3077 \mathrm{~cm}^{-1}, v(\mathrm{C}=\mathrm{O}$ ) $1610 \mathrm{~cm}^{-1}, v(C=N) 1547 \mathrm{~cm}^{-1}, v(C-S) 841 \mathrm{~cm}^{-1}$. UV-Vis (MeOH): $\lambda_{\text {abs }}$ (Mixed $\pi^{-} \Pi^{*}$ and $\left.\mathrm{n}-\Pi^{*}\right) 206 \mathrm{~nm}, 5340 \mathrm{M}^{-}$ ${ }^{1} \mathrm{Cm}^{-1}$; $\lambda_{\text {abs }}$ (Mixed $\pi-\pi^{*}$ and $\left.\mathrm{n}-\Pi^{*}\right) 236 \mathrm{~nm}, 3720 \mathrm{M}^{-1} \mathrm{Cm}^{-}$ '; $\lambda_{\text {abs }}\left(\pi-\Pi^{*}\right) 352 \mathrm{~nm}, 7880 \mathrm{M}^{-1} \mathrm{~cm}^{-1}$. MW: 260.10; MS: m/z $260.10\left(\mathrm{M}^{+}\right)$.

5-Acetyl-4-methyl-2-(4-aminophenol)-1,3-thiazole (4) Yellow powder, yield: $70 \%$; m.p: $138-140{ }^{\circ} \mathrm{C}$; ${ }^{1} \mathrm{H}$ NMR (500 MHz, DMSO-d $\left.d_{6}\right): \delta_{H} 2.38\left(s, 3 \mathrm{H}, \mathrm{CH}_{3}\right), 2.51$ (s, 3H, $\mathrm{CH}_{3}$ ), 6.78 (pseudo-d, J $8.5 \mathrm{~Hz}, 2 \mathrm{H}$, Ar- $\mathrm{CH}$ ), 7.35 (pseudo-d, J $8.5 \mathrm{~Hz}, 2 \mathrm{H}, \mathrm{Ar}-\mathrm{CH}$ ), 9.38 (s br, $1 \mathrm{H}, \mathrm{OH}$ ), $10.46(\mathrm{~s}, 1 \mathrm{H}, \mathrm{NH}$ of thiazole). IR ( $\mathrm{KBr}$ pellet) $: \mathrm{v}(\mathrm{N}-\mathrm{H}) 3080$ $\mathrm{cm}^{-1}, v(\mathrm{O}-\mathrm{H}) 3174 \mathrm{~cm}^{-1}, v$ (aromatic $\left.\mathrm{C}-\mathrm{H}\right) 3031 \mathrm{~cm}^{-1}$, $v(C=O) 1603 \mathrm{~cm}^{-1}, v(C=N) 1580 \mathrm{~cm}^{-1}, v(C-S) 827 \mathrm{~cm}^{-1}$. UV-Vis (MeOH): $\lambda_{\text {abs }}\left(\right.$ Mixed $\pi_{-} \Pi^{*}$ and $\left.n-\Pi^{*}\right) 230 \mathrm{~nm}, 5100$ $\mathrm{M}^{-1} \mathrm{Cm}^{-1} ; \lambda_{\text {abs }}\left(\mathrm{n}-\Pi^{*}\right) 260 \mathrm{~nm}, 3460 \mathrm{M}^{-1} \mathrm{~cm}^{-1} ; \lambda_{\text {abs }}\left(\pi-\Pi^{*}\right) 347$ $\mathrm{nm}, 6920 \mathrm{M}^{-1} \mathrm{~cm}^{-1}$. MW: 248.06; MS: m/z $248.13\left(\mathrm{M}^{+}\right)$.

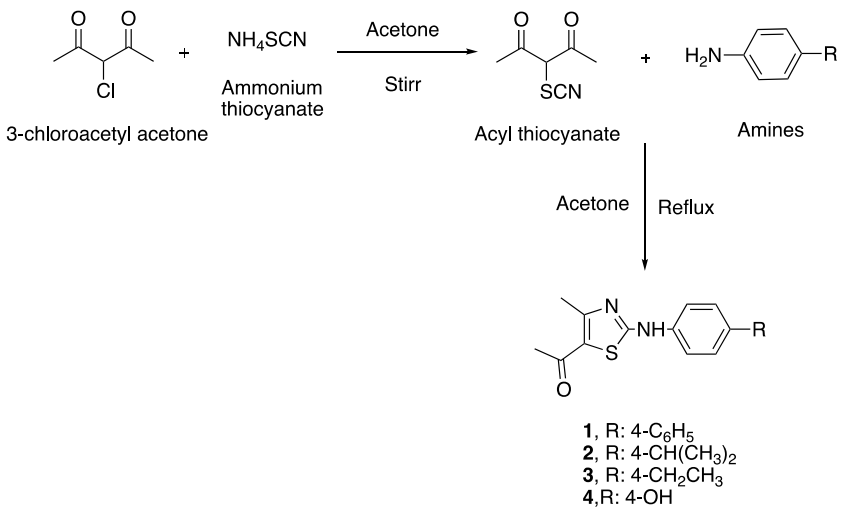

Scheme 1 Synthesis of thiazole derivatives (1-4)

\subsection{Antimicrobial Activity}

\subsubsection{Test Microorganisms}

The cultured and tested microorganisms include both Gram-positive, Gram-negative and fungus. Grampositive used were Bacillus cereus (ATCC11778), Bacillus subtilis (IMRB 145/11C), Staphylococcus aureus (ATCC25923), Staphylococcus epidermidis (ATCC12228) while the Gram-negative selected were Escherichia coli (ATCC25922), Pseudomonas aeruginosa (ATCC27853), Shigella flexneri (IMR5430/07B) and Salmonella typhimurium (IMRS1406/08A). The fungus species used for antifungal activity was Candida albicans (ATCC10231).

\subsubsection{Minimum Inhibitory Concentration Determination (MIC)}

Minimum Inhibitory Concentration (MIC) is the lowest concentration of synthesized compounds required to inhibit growth of microorganisms. This assay was done by using microdilution method [17] by placing the medium into the 96-well plates. Synthesized compounds (1-4) in DMSO at concentration of 10 $\mathrm{mg} / \mathrm{mL}$ were added into first row of microplates and two-fold dilutions of the compounds were made by transferring $100 \mu \mathrm{L}$ solutions into remaining wells. Next, $10 \mu \mathrm{L}$ of the culture suspensions were inoculated into all the wells. The microplates were incubated at $37^{\circ} \mathrm{C}$ for $18-24$ hours for bacteria and at $27^{\circ} \mathrm{C}$ for $24-48$ hours for fungus. Reference drugs used in this assay were Streptomycin $(10 \mu \mathrm{g} / \mathrm{mL})$ for bacterial strains and Clotrimazole $(10 \mu \mathrm{g} / \mathrm{mL})$ for fungal strain. After incubation, $20 \mu \mathrm{L}(0.2 \mathrm{mg} / \mathrm{mL})$ of resazurin solution was added to each well in order to determine the MIC values. The plates were then incubated for another 2 hours. A change from blue to pink indicates reduction of resazurin and microorganisms growth. The MIC was defined as the lowest concentration that prevented this colour from changing. The assay was repeated and triplicate results were observed. 


\subsubsection{Minimum Bactericidal and Fungicidal Concentration Determination (MBC/MFC)}

Minimum bactericidal/fungicidal concentration (MBC/MFC) was determined by transferring and spreading the treated culture broth from the well containing the concentration equal to and higher than the MIC on agar plates [4]. The lowest concentration of the synthesized compounds (1-4) and the standard drugs that required to completely kill the microorganisms (no growth observed on the plates) after incubation at $37^{\circ} \mathrm{C}$ for $18-24$ hours and 27 ${ }^{\circ} \mathrm{C}$ for 24-48 hours for bacteria and fungi, respectively was reported as minimum bactericidal/fungicidal concentration (MBC/MFC).

\subsection{Molecular Docking Study}

In order to determine the possible binding modes of 1 4 that interact with target enzyme; GlcN-6-P synthase, docking studies were performed using the software programme Autodock 4.2. The enzyme as receptor was obtained from the RCSB Protein Data Bank (http://www.pdb.org/pdb/home/home.do) with the $1 \mathrm{MOQ}$ code in pdb file format and used as rigid molecule [18]. At receptor structure, hydrogen atoms were added and water molecules were removed from amino acids. All the ligands (1-4) were drawn using Chem Draw Ultra 7.0 and saved in mol file and energies of the ligands were minimized before converted to pdb file format using Open Babel 2.4.1 software. During docking, the grid dimensions must surround the region of receptor active site. Then, grid box was set at 46,54 and $48 \AA$ for $x, y$ and $z$ axes respectively. The volume of grid box was $31.98 \AA$ by $16.58 \AA$ by $-2.57 \AA$ with points separated by $0.375 \AA$. The grid centre was fixed to $5.472,-6.194$ and -10.694 for $x, y$ and $z$ respectively which covered all the 12 amino acid residues such as Cys300, Gly301, Thr302. Ser303, Ser347, GIn348, Ser349, Thr352, Val399, Ser401, Ala602 and Lys603 in the active pocket. Lamarckian Genetic Algorithm was used as docking algorithm with 100 runs, 150 population size, 27,000 maximum numbers of generations and 2,500,000 maximum numbers of energy evaluation.

\subsection{RESULTS AND DISCUSSION}

\subsection{Chemistry}

In this study, four new thiazole derivatives (1-4) have been successfully synthesized by reaction of haloketone; 3-chloroacetyl acetone with ammonium thiocyanate and selected primary amine compounds according to the procedure that illustrated in Scheme 1. The thiazole compounds were synthesized according to the reported method in literature [19]. All derivatives were obtained in good percentage yield of $70-76 \%$. The synthesized compounds were characterized by using 'H NMR, FTIR, UV-Vis, Mass Spectrometry and melting point. There are five important bands in all FT-IR spectra such as $v(\mathrm{NH})$, $v(\mathrm{CH}), \mathrm{v}(\mathrm{C}=\mathrm{O}), \mathrm{v}(\mathrm{C}=\mathrm{N})$ and $\mathrm{v}(\mathrm{C}=\mathrm{S})$. N-H stretching band can be observed in the region of $3281-3080 \mathrm{~cm}$ 1. Next, absorption band of aromatic $\mathrm{C}-\mathrm{H}$ can be seen at $3081-3031 \mathrm{~cm}^{-1} . \mathrm{C}=\mathrm{O}$ absorption band appeared as intense peak at 1614-1603 $\mathrm{cm}^{-1}$ as a result of high dipole moment due to partial negative charge character of oxygen atom $[20,21]$. $\mathrm{C}=\mathrm{N}$ and $\mathrm{C}-\mathrm{S}$ stretching bands can be observed at $1580-1523 \mathrm{~cm}^{-1}$ and $841-756 \mathrm{~cm}^{-1}$ respectively similar as reported by [22]. Figure 1 shows the IR spectrum of 5-acetyl-4methyl-2-(4-aminobiphenyl)-1,3-thiazole (1) as representative of the series.

Meanwhile, the 'H NMR spectra of 1-4 exhibited similar characteristic of two singlet peaks at $\delta_{H} 2.38$ $2.57 \mathrm{ppm}$ which were assigned as methyl protons at 4and 5- positions. In the range of $\delta_{H}$ 7.21-7.59 ppm, roofing effect due to para substituted phenyl group can be observed in all compounds. Whereas, the $\mathrm{NH}$ of thiazole was found to be shifted to downfield region ( $\delta_{H}$ 10.46-10.89 ppm) and appeared as a broad singlet peak. The presence of $\mathrm{NH}$ resonance is considered as evident to prove successful formation of thiazole ring $[23,24]$. Figure 2 shows the $1 \mathrm{H}$ NMR spectrum of 5 acetyl-4-methyl-2-(4-aminobiphenyl)-1,3-thiazole (1) as representative of the series.

In UV-Vis absorption study, spectra for all compounds exhibited similar pattern of three observable bands. The highest peaks which appeared at 209-260 nm was assigned as mixed $\pi-\pi^{*}$ and $n-\pi^{*}$ transitions which attributed by unsaturated moiety as well as presence of lone pair of electron in the molecule. Molecular ion peak in mass spectra for all compounds $[\mathrm{m} / \mathrm{z}]^{+}: 308.12,274.10,260.10$ and 248.13 for compounds $\mathbf{1}, \mathbf{2}, \mathbf{3}$ as well as 4 respectively. The values were found to be in good agreement with theoretical molecular weight of each compound. 


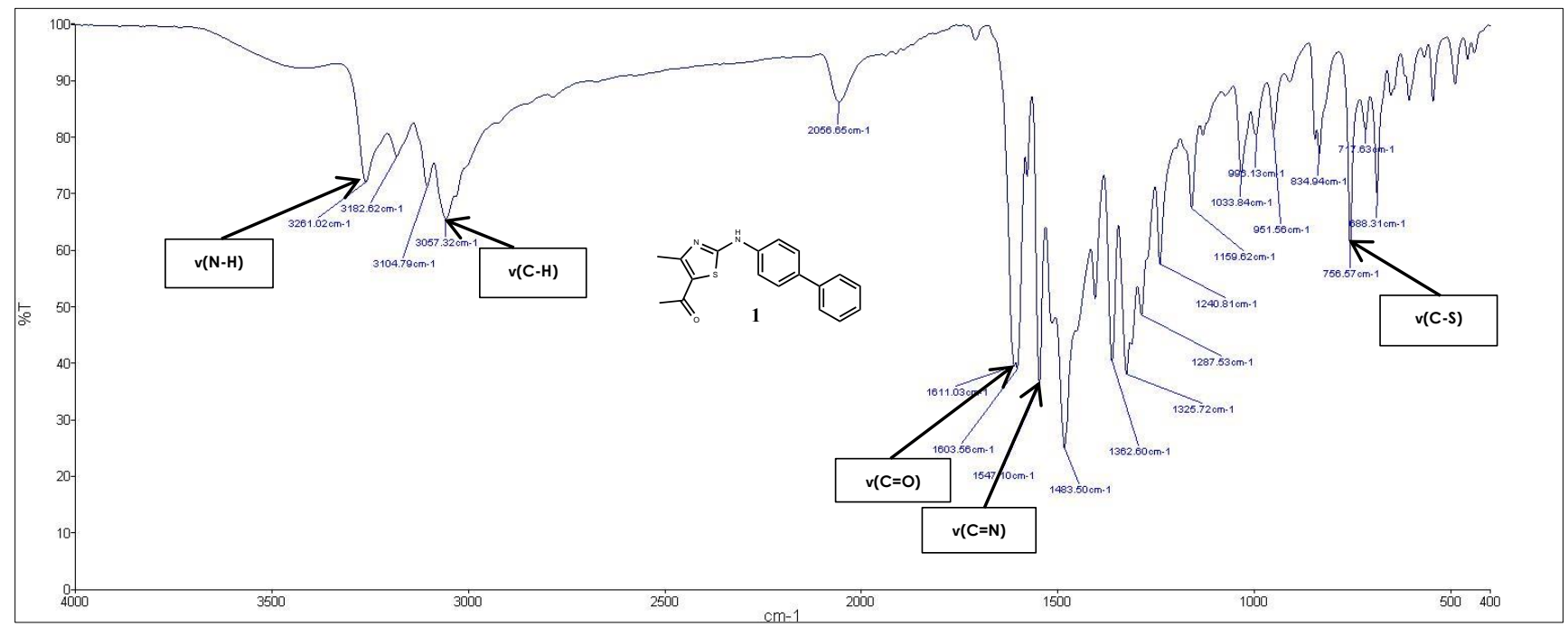

Figure 1 Infrared spectrum of 5-acetyl-4-methyl-2-(4-aminobiphenyl)-1,3-thiazole (1) as representative of the group

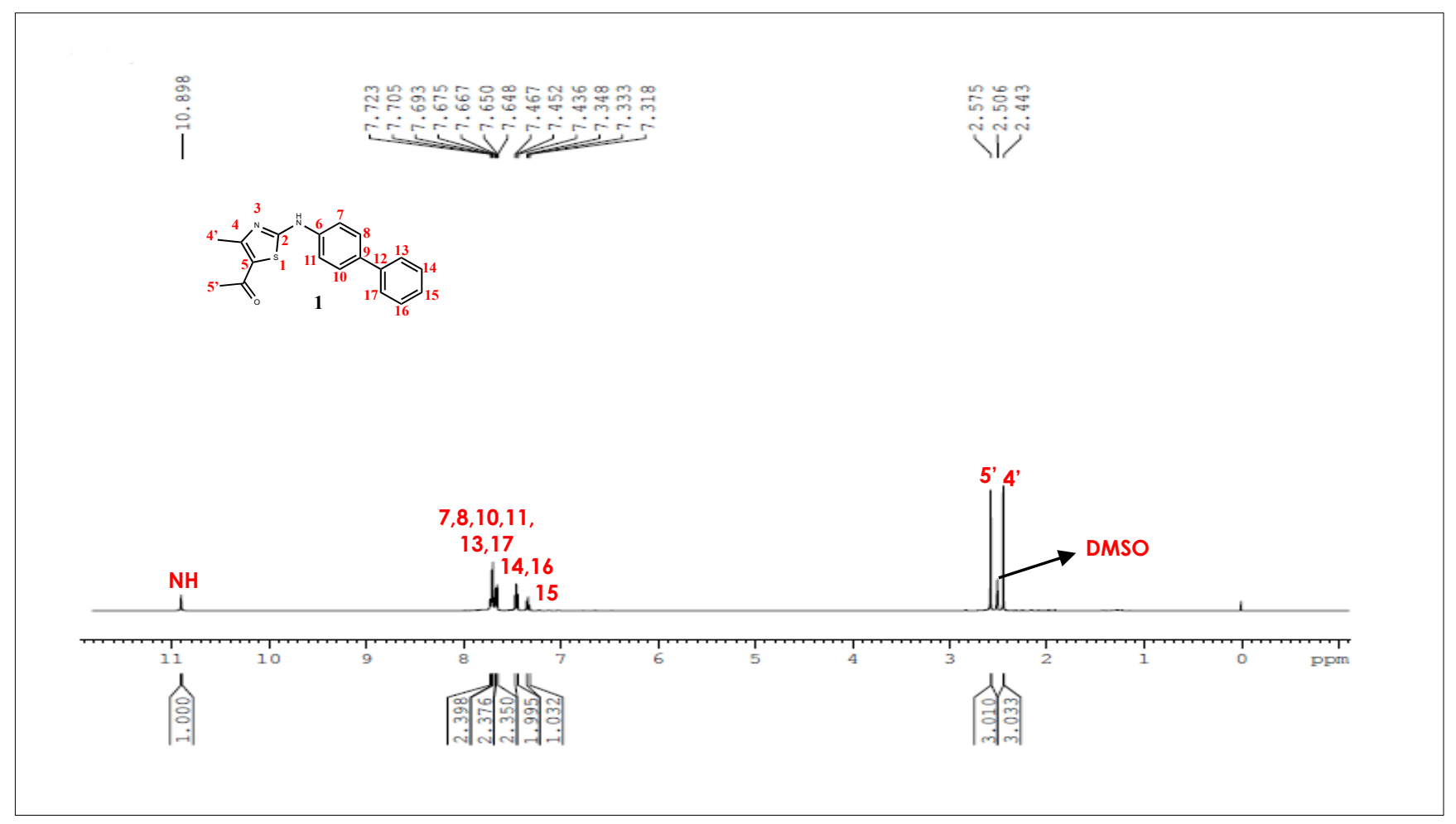

Figure 2 'H NMR spectrum of 5-acetyl-4-methyl-2-(4-aminobiphenyl)-1,3-thiazole (1)

\subsection{Antimicrobial Activity}

All synthesized compounds 1-4 were analysed at 10.0 $\mathrm{mg} / \mathrm{mL}$ for their antimicrobial activity against eight bacterial strains (four Gram-positive and four Gramnegative) and fungus strain. MIC value was considered the lowest concentration that displayed no growth after incubation. The results revealed that all synthesized compounds exhibited antimicrobial activity with MIC values ranging from $1.25 \mathrm{mg} / \mathrm{mL}$ to
$5.0 \mathrm{mg} / \mathrm{mL}$. Overall, compound 1 with the biphenyl structure as substituent exhibited the greatest antibacterial activity. Particularly, compound 1 exhibited MIC values of $1.25,2.5,1.25,2.5 \mathrm{mg} / \mathrm{mL}$ against $B$. cereus, S. epidermidis, S. flexneri and S.typhimurium respectively as compared to other compounds. It was reported that delocalization of electrons in biphenyl structure of compound 1 plays crucial role in increasing the antibacterial behaviour [25]. Whereas, compound $\mathbf{2}$ and $\mathbf{3}$ with isopropyl and 
ethyl as substituent, respectively show lower antibacterial activity. This observation suggested that the introduction of ethyl or branch (electron donating group) into the phenyl ring could not enhance the inhibitory activity [26]. However, compound $\mathbf{4}$ with $\mathrm{OH}$ moiety at the para position of phenyl ring of thiazole compound showed the lowest antibacterial activity. Besides, MIC results demonstrate that synthesized compound $\mathbf{1}$ and $\mathbf{2}$ displayed two times more potent antibacterial activity with concentration at 1.25 $\mathrm{mg} / \mathrm{mL}$ against $B$. cereus and S. flexneri as compared to synthesized compounds $\mathbf{3}$ and $\mathbf{4}$ with concentration at $2.5 \mathrm{mg} / \mathrm{mL}$. However, lower MIC value of Streptomycin (standard) was observed at concentration at 0.078 and $0.16 \mathrm{mg} / \mathrm{mL}$ against $B$. cereus and $\mathrm{S}$. flexneri respectively.

Table1 Antimicrobial activity of title compounds. The negative control DMSO showed no activity

\begin{tabular}{|c|c|c|c|c|c|c|}
\hline \multicolumn{7}{|c|}{$\begin{array}{c}\text { Minimum Inhibitory Concentration; MIC } \\
\text { (Minimum Bactericidal/Fungicidal Concentration; } \\
\text { MBC/MFC) }\end{array}$} \\
\hline & \multicolumn{4}{|c|}{$\begin{array}{l}\text { Thiazole Compounds } \\
\text { (mg/mL) }\end{array}$} & \multicolumn{2}{|c|}{$\begin{array}{l}\text { Standard } \\
(\mu \mathrm{g} / \mathrm{mL})\end{array}$} \\
\hline & 1 & 2 & 3 & 4 & $S$ & C \\
\hline \multirow{2}{*}{$B C$} & 1.25 & 1.25 & 1.25 & 2.5 & 0.078 & - \\
\hline & (5.0) & (5.0) & (5.0) & $(10.0)$ & $(0.16)$ & \\
\hline \multirow{2}{*}{ BS } & 2.5 & 2.5 & 2.5 & 2.5 & 0.078 & - \\
\hline & (5.0) & (10.0) & (5.0) & (5.0) & $(0.31)$ & \\
\hline \multirow{2}{*}{ SA } & 2.5 & 2.5 & 2.5 & 2.5 & 0.31 & - \\
\hline & (5.0) & (5.0) & (5.0) & $(10.0)$ & $(0.31)$ & \\
\hline \multirow{2}{*}{ SE } & 2.5 & 5.0 & 5.0 & 5.0 & 0.078 & - \\
\hline & (5.0) & $(10.0)$ & $(10.0)$ & $(10.0)$ & $(0.31)$ & \\
\hline \multirow{2}{*}{$E C$} & & & 5.0 & 5.0 & 0.078 & - \\
\hline & (5.0) & $(5.0)$ & (5.0) & $(10.0)$ & $(0.16)$ & \\
\hline \multirow{2}{*}{$P A$} & 2.5 & 2.5 & 2.5 & 2.5 & 0.078 & - \\
\hline & (2.5) & $(2.5)$ & (2.5) & (2.5) & $(0.078)$ & \\
\hline \multirow{2}{*}{$S F$} & 1.25 & 1.25 & 2.5 & 2.5 & 0.16 & - \\
\hline & (5.0) & $(5.0)$ & (5.0) & (5.0) & $(1.25)$ & \\
\hline \multirow{2}{*}{$S T$} & 2.5 & 5.0 & 5.0 & 5.0 & 0.32 & - \\
\hline & (5.0) & $(5.0)$ & (5.0) & (5.0) & $(0.32)$ & \\
\hline \multirow{2}{*}{$C A$} & 2.5 & 2.5 & 2.5 & 5.0 & - & 0.078 \\
\hline & (5.0) & $(5.0)$ & (5.0) & (5.0) & & $(1.25)$ \\
\hline
\end{tabular}

Meanwhile, the average of lowest concentration of 14 that completely killed all the bacterial strains and fungus tested were between 2.5 and $10.0 \mathrm{mg} / \mathrm{mL}$, respectively. For instance, $M B C$ values for P.aeruginosa (Gram-negative) and S. aureus (Gram positive) against all compounds tested were 2.5 and $5.0 \mathrm{mg} / \mathrm{mL}$. Whereas the MFC values of $\mathbf{1 - 4}$ against $C$. albicans showed equal value of $5.0 \mathrm{mg} / \mathrm{mL}$. The details of antimicrobial results of the thiazole derivatives towards bacteria and fungus are shown in Table 1. The results of antimicrobial activity test revealed that compound $\mathbf{1}$ showed the highest activity against all microbes tested followed by compounds 2, 3 and 4. According to the previous literature, substituent on the para position of phenyl skeleton plays a major role in the inhibition of bacteria and fungi [27]. In general, all the tested compounds exhibited promising behaviour as antimicrobial agents.

\subsection{Molecular Docking}

Inhibition of the GlcN-6-P synthase gives a major role to the population of bacteria by disturbing the production and biosynthesis of cell membrane $[15,28]$. In this work, orientation of ligands interaction in the active site of the GlcN-6-P synthase was determined by automated docking [16]. Figure 3 displayed the best generated conformers after 100 runs for $\mathbf{1 - 4}$ in the binding pocket of GlcN-6-P synthase. The docking of ligands molecules with enzyme revealed that all compounds exhibited hydrogen bonding interactions more than one amino residues such as Gly348, Thr355 and Ser401 in the active pockets of GlcN-6-P synthase. Binding energy and binding interactions of the ligands were predicted in the study which are tabulated in Table 2. Docking results found that amino acid residues listed in Table 2 play essential role in the inhibition $[29,30]$.

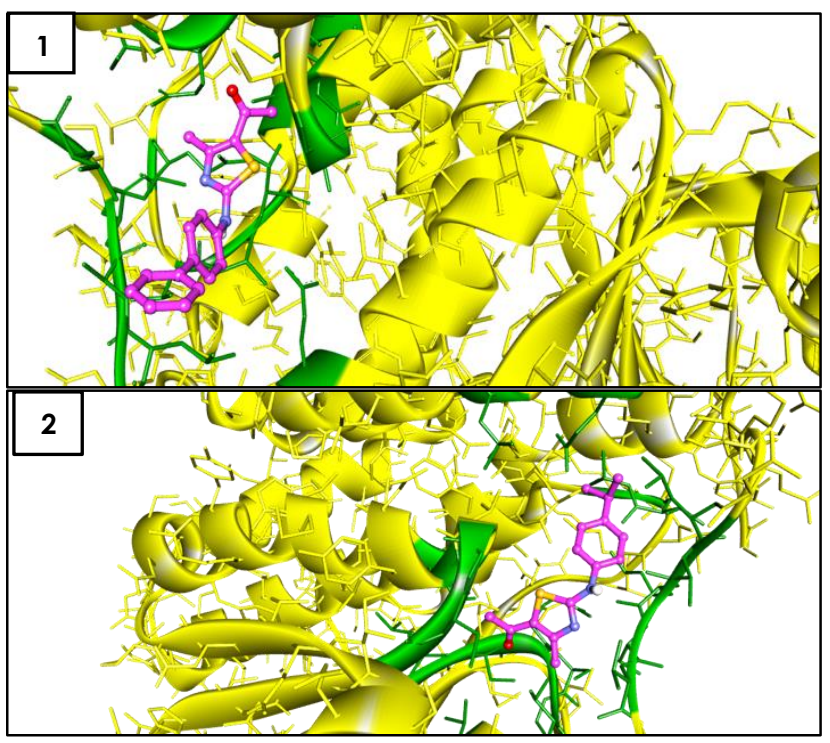




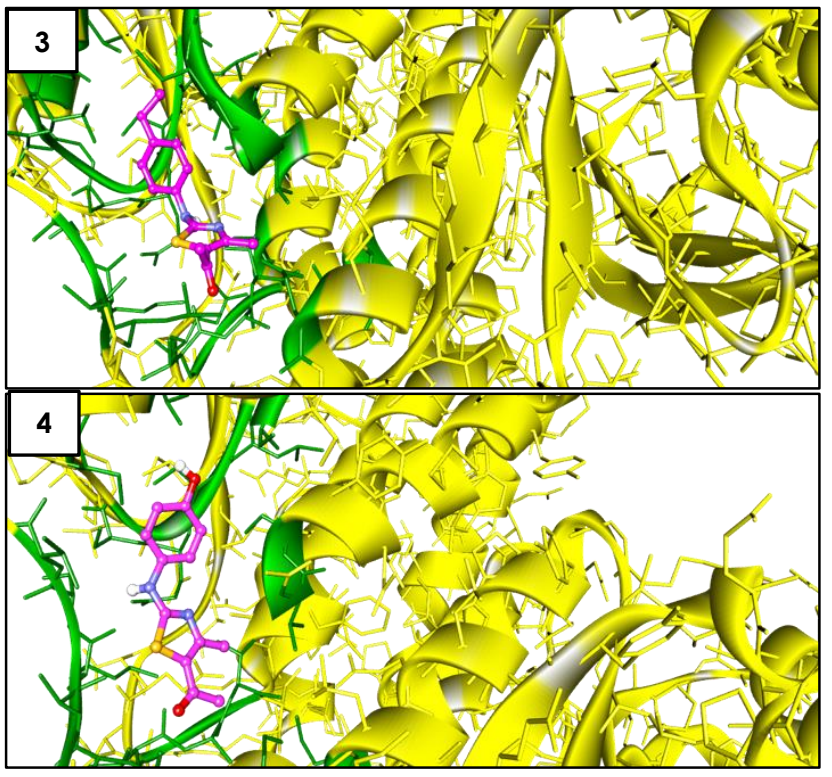

Figure 3 Docked conformations of 1-4 (thick stick model) in the active site of GlcN-6-P synthase (thin stick and solid ribbon model)

Compound 1 was found to be the most potent derivative prepared in this series with high number of hydrogen bonding interactions with amino acid residues namely GIn348, Ser303, Thr302 and Val399 compared to 2 (Gln348, Ser303, Thr352), 3 (Thr302, Ser401) and 4 (Lys603, Thr355). From the molecular structure of ligands, it can be observed that amine (NH) group in all thiazole derivatives (1-4) form hydrogen bonding with amino acid residues namely

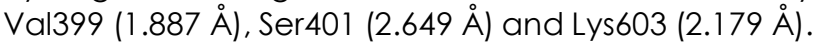
Besides, hydroxyl $(\mathrm{OH})$ group that is attached to the phenyl group in compound $\mathbf{4}$ tends to form hydrogen bonding with Thr355 (2.319 $\AA$ ). The presence of different substituents attached on phenyl of thiazole derivatives which is benzene, isopropyl, ethyl and hydroxyl respectively affects the interaction performance of ligands towards amino acid residues by forming hydrogen bonding which inhibiting the formation of diphosphate N-acetylglucosamine (UDPGlcNAc) which is essential for macromolecules building block for cell wall assembly and significantly reduced the lifespan of bacteria $[28,31]$.

On the other hand, based on molecular docking result, compound 1 displayed the best binding energy $(-7.32 \mathrm{kcal} / \mathrm{mol})$ compared to other ligands in following order; $\mathbf{1}>\mathbf{2}>\mathbf{3}>\mathbf{4}$. Excellent binding energy of inhibitor-enzyme complex is mostly due to the strong hydrogen bonds that formed between them with bond length less than $3.00 \AA$ [28]. This finding suggested that the increasing number of hydrogen bonding interactions that was formed between ligand and amino acid residues will produce lowest value of binding energy [32]. Therefore, it can be suggested that molecular docking results provide valuable information about the interaction of synthesized thiazole compounds (1-4) with antimicrobial assay.
Table 2 Docking results of 1-4 and standard drugs against GlcN-6-P synthase

\begin{tabular}{|c|c|c|c|}
\hline Ligand & $\begin{array}{c}\text { Binding } \\
\text { Energy } \\
\text { (kcal/mol) }\end{array}$ & $\begin{array}{c}\text { Amino } \\
\text { Acid } \\
\text { Residues }\end{array}$ & $\begin{array}{l}\text { H-bonding } \\
\text { (distance } \\
\AA \text { A) }\end{array}$ \\
\hline \multirow[t]{4}{*}{1} & -7.32 & Gln348 & 2.838 \\
\hline & & Ser303 & 2.708 \\
\hline & & Thr302 & 2.679 \\
\hline & & Val399 & 1.887 \\
\hline \multirow[t]{3}{*}{2} & -7.31 & Gln348 & 3.076 \\
\hline & & Ser303 & 2.515 \\
\hline & & Thr352 & 3.161 \\
\hline \multirow[t]{2}{*}{3} & -7.20 & Thr302 & 2.827 \\
\hline & & Ser401 & 2.649 \\
\hline \multirow[t]{2}{*}{4} & -6.76 & Lys603 & 2.179 \\
\hline & & Thr355 & 2.319 \\
\hline \multirow[t]{7}{*}{ Streptomycin } & -7.66 & Val399 & 1.244 \\
\hline & & Ser401 & 1.393 \\
\hline & & Cys300 & 1.231 \\
\hline & & Ala602 & 1.238 \\
\hline & & Asn 600 & 1.235 \\
\hline & & Thr302 & 1.245 \\
\hline & & Glu488 & 1.448 \\
\hline \multirow[t]{4}{*}{ Clotrimazole } & -8.18 & Gln348 & 2.839 \\
\hline & & Ser401 & 2.649 \\
\hline & & Ser303 & 3.081 \\
\hline & & Thr352 & 2.909 \\
\hline
\end{tabular}

\subsection{CONCLUSION}

Herein, a series of new 2, 4, 5-trisubstituted-1,3-thiazole derivatives were successfully synthesized, characterized with determination of their antimicrobial activities against bacterial strains and fungus. All synthesized compounds showed significant activity against tested microorganisms with the MIC and $M B C$ values in the range of $2.5-10.0 \mathrm{mg} / \mathrm{mL}$ and $1.25-5.0 \mathrm{mg} / \mathrm{mL}$ respectively. In particular, compound 1 was found to be more significant and promising antimicrobial agent due to its good MIC and MBC values in the range of $1.25-2.5 \mathrm{mg} / \mathrm{mL}$ and $2.5-5.0$ $\mathrm{mg} / \mathrm{mL}$ respectively. Molecular docking studies also revealed that compound $\mathbf{1}$ has the lowest binding energy and can be considered as good inhibitor towards GlcN-6-P synthase. Further research is needed for this purpose including the combinations of synthesized compounds with conventional drugs (synergism study) as well as their mode of action against microorganisms.

\section{Acknowledgement}

This research work was kindly supported by the Ministry of Education Malaysia FRGS14-15-0392, Department of Chemistry and Biotechnology, Kulliyyah of Science, International Islamic University Malaysia (IIUM) as well as Central Laboratory, Universiti Malaysia Pahang. 


\section{References}

[1] Upmanyu, N., Kumar, S., Shah, K. and Mishra, P. 2012. Synthesis and Antimicrobial Studies of Some 4-(Substituted)Ethanoylamino-3-Mercapto-5-(4-Substituted) Phenyl-1,2,4Triazoles. Dhaka University Journal of Pharmaceutical Sciences. $11(1):$ 7-18.

[2] Araniciu, C., Marutescu, L., Oniga, S., Oniga, O., Chifiriuc, M. C. and Palage, M. 2014. Evaluation of The Antimicrobial and Anti-Biofilm Activity of Some 4,2 and 5,2 Bisthiazoles Derivatives. Digest Journal of Nanomaterials and Biostructures. 9(1): 123-131).

[3] Mulyaningsih, S., Sporer, F., Zimmermann, S., Reichling, J. and Wink, M. 2010. European Journal of Integrative Medicine. 17(13): 1061-1066. doi: 10.1016/j.phymed.2010.06.018.

[4] Elexson, N., Afsah-Hejri, L., Rukayadi, Y., Soopna, P., Lee, H. Y., Tuan Zainazor, T. C., Nor Ainy, M., Nakaguchi, Y., Mitsuaki, N. and Son, R. 2014. Effect of Detergents as Antibacterial Agents on Biofilm of Antibiotics-Resistant Vibrio Parahaemolyticus Isolates. Food Control. 35 (1): 378385.

[5] Alasmary, F. A. S., Snelling, A. M., Zain, M. E., Alafeefy, A. M., Awaad, A. S. and Karodia, N. 2015. Synthesis and Evaluation of Selected Benzimidazole Derivatives as Potential Antimicrobial Agents. Molecules. 20: 15206-15223. doi: 10.3390/molecules200815206.

[6] Kaur, H., Kaur, H., Chawla, A. and Baghel, U. S. 2014. Synthesis and Antimicrobial Evaluation of Substituted Thiazole Compounds. International Journal of ChemTech Research. 6(2): 1377-1380.

[7] Ayati, A., Emami, S., Asadipour, A., Shafiee, A. and Foroumadi, A. 2015. Recent Applications of 1,3-Thiazole Core Structure in The Identification of New Lead Compounds and Drug Discovery. European Journal of Medicinal Chemistry. 97: 699-718. doi: 10.1016/j.ejmech.2015.04.015.

[8] Arora, P., Narang, R., Bhatia, S. Nayak, S. K., Singh, S. K. and Narasimhan, B. 2015. Synthesis, Molecular Docking and QSAR Studies of 2,4-Disubstituted Thiazoles as Antimicrobial Agents. Journal of Applied Pharmaceutical Sciences. 5(2): 28-48. doi: 10.7324/JAPS.2015.50206.

[9] Hamid, B., Adel, B. and Reza, A. 2016. One-Pot Synthesis and Characterization of Highly Functionalized Thiazoles. Iranian Journal of Chemistry and Chemical Engineering. 35(4): 31-37.

[10] Rouf, A. and Tanyeli, C. 2015. Bioactive Thiazole and Benzothiazole Derivatives. European Journal of Medicinal Chemistry. 97: 911-927. http://dx.doi.org/10.1016/j.ejmech.2014.10.058.

[11] Cai, W., Liu, A., Li, Z., Dong, W., Liu, X. and Sun, N. 2016. Synthesis and Anticancer Activity of Novel Thiazole-5Carboxamide Derivatives. Applied Sciences. 6(8): 1-10. doi: 10.3390/app6010008.

[12] Dawood, K., Eldebss, T. M. A., El-Zahabi, H. S. A. and Yousef, M. H. 2015. Synthesis and Antiviral Activity of Some New Bis1,3-Thiazole. European Journal of Medicinal Chemistry. 102: 266-276. http://dx.doi.org/10.1016/j.ejmech.2015.08.005.

[13] Yu, Y., Chen, H., Wang, L., Chen, X. and Fu, B. 2009. A Facile Synthesis of 2,4-Disubstituted Thiazoles Using $\mathrm{MnO}_{2}$ Molecules. 14(12): 4858-4865. doi: 10.3390/molecules 14124858.

[14] Zhao, H., Cui, G., Jin, J., Chen, X. and Xu. B. 2016. Synthesis and Pinl Inhibitory Activity of Thiazole Derivatives. Bioorganic \& Medicinal Chemistry. 24(22): 5911-5920. http://dx.doi.org/10.1016/j.bmc.2016.09.049.

[15] Venkatesh, T., Bodke, Y. D., Kenchappa, R. and Telkar, S. 2016. Synthesis, Antimicrobial and Antioxidant Activity of Chalcone Derivatives Containing Thiobarbitone Nucleus. Medicinal Chemistry. 6(7): 440-448 http://dx.doi.org/10.4172/2161-0444.1000383.

[16] Sarojini, B. K., Krishna, B. G., Darshanraj, C. G., Bharath, B. R. and Manjunatha, H. 2010. Synthesis, Characterization, in vitro and Molecular Docking Studies of New 2,5-Dichloro Thienyl Substituted Thiazole Derivatives for Antimicrobial Properties. European Journal of Medicinal Chemistry. 45(8): 3490-3496. doi: 10.1016/j.ejmech.2010.03.039.

[17] Balouiri, M., Sadiki, M. and Ibnsouda, S. K. 2016. Methods for in vitro Evaluating Antimicrobial Activity: A Review. Journal of Pharmaceutical Analysis. 6(2): 71-79. http://dx.doi.org/10.1016/j.jpha.2015.11.005.

[18] Catalano, A., Carocci, A., Defrenza, I., Muraglia, M., Carrieri, A., Bambeke, F. V., Rosato, A. and Corbo, F. 2013. 2-Aminobenzothiazole Derivatives: Search for New Antifungal Agents. European Journal of Medicinal Chemistry. 64: 357-364 http://dx.doi.org/10.1016/j.ejmech.2013.03.064.

[19] Jumal, J., Latip, J. and Yamin, B. M. 2006. 2-(4-Fluoroaniline)4,5-Dimethyl-1,3-Thiazole. Acta Crystallographica Section E Structure Report Online. 62(4): 1174-1185. doi: $10.1107 /$ S1600536806026353.

[20] Patel, D. D., Patel, M. S., Patel, V. S. and Patel, K. C. 2014. Synthesis and Benzothiazoles Derivatives, Their Schiff Bases and Its Anti-Infective Biological Activities. International Journal of Advanced Research. 2(30): 1048-1054.

[21] Khattab, S. N. 2005. Synthesis and Biological Activity of Novel Amino Acid-(N'Benzoyl) Hydrazide and Amino Acid(N'-Nicotinoyl) Hydrazide derivatives. Molecules. 10: 12181228.

[22] Parašotas, I., Anusevičius, K., Jonuškienè, I. and Mickevičius, V. 2014. Synthesis and Antibacterial Activity of Ncarboxyethyl-N-(4-hydroxyphenyl)-2-aminothiazoles and Dihydrothiazolones. Chemija. 25 (2): 107-114.

[23] Anbazhagan, R. and Sankaran, K. R. 2013. Syntheses, Spectral Characterization, Single Crystal X-Ray Diffraction and DFT Computational Studies of Novel Thiazole Derivatives. Journal of Molecular Structure. 1050: 73-80. http://dx.doi.org/10.1016/j.molstruc.2013.07.019.

[24] Desai, N. C., Makwana, A. H. and Rajpara, K. M. 2016. Synthesis and Study of 1,3,5-Triazine Based Thiazole derivatives as Antimicrobial Agents. Journal of Saudi $\begin{array}{lll}\text { Chemical } & \text { Society. } & \text { 20(1): }\end{array}$ http://dx.doi.org/10.1016/j.jscs.2012.12.004.

[25] Gupta, V. and Kant, V. 2013. A Review on Biological Activity of Imidazole and Thiazole Moieties and Their Derivatives. Science International. 1(7): 253-260. doi: 10.17311/sciintl.2013.253.260.

[26] Li, J., Li, D., Wang, R., Sun, J. Dong, J., Du, Q., Fang, F., Zhang, W. and Zhu, H. 2014. Design and Synthesis of Thiazole Derivatives as Potent FabH Inhibitors with Antibacterial Activity. European Journal of Medicinal Chemistry. $\quad$ 75: 438-447. http://dx.doi.org/10.1016/j.ejmech.2013.11.020.

[27] Siddiqui, N., Arshad, M. F., Ahsan, W. and Alam, S. 2009. Thiazoles: A Valuable Insight into the Recent Advances and Biological Activities. International Journal of Pharmaceutical Sciences and Drug Research. 1(3): 136143.

[28] Fikrika, H., Ambarsari, L. and Sumaryada, T. 2016. Molecular Docking Studies of Catechin and Its Derivatives as AntiBacterial Inhibitor for Glucosamine-6-Phosphate Synthase. Earth and Environmental Science. 31: 1-6. doi: 10.1088/1755-1315/31/1/012009.

[29] Ansari, A., Ali, A., Asif, M., Rauf, M. A., Owais, M. and Shamsuzzaman. 2018. Facile One-pot Multicomponent Synthesis and Molecular Docking Studies of Steroidal Oxazole/Thiazole Derivatives with Effective Antimicrobial, Antibiofilm and Hemolytic Properties. Steroids. 18: 1-49. doi: https://doi.org/10.1016/j.steroids.2018.04.003.

[30] Hareesh, H. N., Nagananda, G. S., Minchitha, K. U., Swetha, S., Ganai, S. A., Dhananjaya, B. L., Nagaraju, N. and Kathyayini, N. 2015. Synthesis, Free Radical Scavenging Activity, Antimicrobial and Molecular Docking Studies of Novel Pyrazine 2-Carboxylic Acid Derivatives of Piperazines. Research Journal of Pharmaceutical, Biological and Chemical Sciences. 6(4): 1914-1926. 
[31] Miszkiel, A., Wojciechowski, M. and Milewki, S. 2011. Long Range Molecular Dynamics Study of Regulation of Eukaryotic Glucosamine-6-Phosphate Synthase Activity by UDC-GICNac. Journal of Molecular Modeling. 17: 31033115. doi: 10.1007/s00894-011-1003-x.
[32] Gull, Y., Rasool, N., Noreen, M., Altaf, A. A., Musharraf, S. G., Zubair, M., Nasim, F., Yaqoob, A., DeFeo, V. and Zia-Ul- Haq, M. 2016. Synthesis of N-(6-Arylbenzo[d] thiazole-2acetamide Derivatives and Their Biological Activities: An Experimental and Computational Approach. Molecules. 21 (266): 1-7. doi: 10.3390/molecules21030266. 